Article

\title{
Agroecology and Ecological Intensification. A Discussion from a Metabolic Point of View
}

\author{
Manuel González de Molina * and Gloria I. Guzmán Casado \\ Agroecosystems History Lab, Universidad Pablo de Olavide, 41013 Seville, Spain; giguzcas@upo.es \\ * Correspondence: mgonnav@upo.es; Tel.: +34-954-349-099
}

Academic Editor: Jennifer Reeve

Received: 26 November 2016; Accepted: 5 January 2017; Published: 10 January 2017

\begin{abstract}
This paper documents the origin and conceptual ambiguity of the terms Sustainable, Ecological and Agroecological Intensification. It defines the concept of Ecological Intensification from an agroecological perspective, and examines in energy terms whether it may be sustainable. To illustrate the theory, we apply Land Cost of Sustainable Agriculture (LACAS) methodology to Spanish agriculture, which is representative of Mediterranean agroclimatic conditions. As a result, we demonstrate the impossibility of generalizing an extensive Organic Farming (OF) scenario under the techniques currently used by organic farmers. This is due to the fact that it would bring about a reduction of $13 \%$ in agricultural production. Which necessarily means that OF has to be intensified under agroecological criteria. This option is also explored in two scenarios. As a result, we show that it is possible to compensate the yield gap between $\mathrm{OF}$ and conventional agriculture by implementing low-entropy internal loop strategies which reduce the land cost of generating the necessary nitrogen flows. However, these cannot exceed the limits established by the structure of Spanish territory. That is, agroecological intensification cannot be prolonged indefinitely over time since it is limited by the land available.
\end{abstract}

Keywords: land cost of sustainability; organic farming; Spain; Agroecological Intensification

\section{Introduction}

There is a growing conviction in the scientific community, governments, and think tanks that input-intensive or industrial agriculture is not viable. Its negative impacts on the environment and health, its inefficacy in providing a decent income for farmers, its high reliance on fossil fuels and its high vulnerability to climate change have convinced them of the need for a change in the model. International organizations such as the Food and Agriculture Organization of the United Nations (FAO) [1] recognize that industrial agriculture will be unable to meet the growing demand for food caused by population growth (more than 9 billion people by 2050) and by the increase in meat and dairy consumption, especially in emerging countries. This will raise the demand for food between $70 \%$ [1] and $100 \%$ [2]. In this context, many alternative agricultural models have emerged. Among the most successful is ecological or sustainable intensification. The debate has also reached the field of Agroecology, where the term Agroecological Intensification has come into currency. But does this term make sense? Can intensification from an agroecological point of view be sustainable? If so, in what circumstances and for how long?

The term Sustainable Intensification originated in the 1990s to solve growing hunger and food security problems in Sub-Saharan Africa [3-7]. But the term has gained great relevance over the last decade as a result of the current economic and financial crisis. Today the term has expanded worldwide and is commonly used in the academic literature and reports by international organizations and agricultural think tanks (the FAO, RISE International, the UK's Royal Society, etc.). Sustainable intensification refers to a form of production wherein "yields are increased without adverse 
environmental impact and without the cultivation of more land" [8] and without undermining the capacity to continue producing food in the future [9]. Since it is not possible to increase the arable lands at the expense of biodiversity, "the next increase in global food output must come from continued intensification of existing agricultural land and [ ... ] this must be accompanied by a steep reduction in the negative environmental consequences of agriculture" ... [10]. Nevertheless, "the term denotes an aspiration of what needs to be achieved, rather than a description of existing production systems, whether this be conventional high input farming, or smallholder agriculture, or approaches based on organic methods" [11] (p. 8).

Thus, this term covers very different agricultural management models. As stated in the RISE Report: an individual farm wanting to practice sustainable intensification can adopt "one of the farming systems which have been created specifically for their sustainability attributes: agroecology, biodynamic, organic, integrated and precision farming, and conservation agriculture" [12] (p. 10). In fact, "sustainable intensification is not wedded to any one agricultural approach" [11] (p. 17).

A large number of think tanks and international organizations that defend the status quo understand the term sustainable intensification actually to mean an improvement in the efficiency of input use, without changing the diet, industrial farming model or food market dynamics: "The prime objective ( . . ) is to improve the resource efficiency of agriculture" [12] (p. 28), [13]. In other words, "the prime goal of sustainable intensification is to raise productivity (as distinct from increasing the volume of production) while reducing environmental impacts" [11] (p. 14). This ambiguity regarding farming models may legitimize the high-input model based on agricultural growth with a new environmentalist language: "Improving agricultural growth is also imperative for reducing poverty, in itself a cause of some forms of environmental degradation and hunger" [7] (p. 5). More explicitly, some authors suggest sustainable intensification actually justifies a new high-input model and the use of technologies, such as biotechnology [14] and more specifically, genetically modified organism (GMO) seeds. It simply means greening the status quo ... "As such, the concept has been endorsed by some interest groups, particularly the farming industry, and criticized by others, particularly those from within the environmental community [11] (p. 9).

The concept of sustainable intensification has been closely linked to the debate on land sharing/land sparing [15,16], [11] (p. 28):

"This argument has been portrayed as one of specialization: should land be managed simultaneously to produce, say, biodiversity and yield (the land is 'shared' between services), or should land be specialized in some places to produce yield and in others to produce biodiversity (land 'sparing')? Given that there is an inherent trade off assumed in this argument, a larger yield in agricultural land implies that land can be 'spared' for biodiversity."

On the other hand, the term Ecological Intensification was coined by Cassman [17] when studying the possibilities of further intensification of cereal production in order to meet the increase in food demand but with acceptable standards of environmental quality. Unlike the term sustainable intensification, its supporters seem to suggest an organic management model, given the impossibility of intensifying production with chemical inputs without damaging agroecosystems. The FAO has defined "ecological intensification" within the framework of Organic Farming (OF) as "maximization of primary production per unit area without compromising the ability of the system to sustain its productive capacity" [1]. In other words, ecological intensification is based on "intensification in the use of the natural functionalities that ecosystems offer" [18]. In a similar direction, the term Agroecological Intensification has been proposed, and "focuses on 'natural means' of increasing outputs, for example by incorporating legumes into fields or using agroforestry techniques" [14] (p. 2).

But many of those who promote agroecological intensification are using this term ambiguously. Certainly, the term fits well into Agroecology: "Agroecological Intensification is a management approach that integrates ecological principles and biodiversity management into farming systems with the aim of increasing farm productivity, reducing dependency on external inputs, and sustaining or 
enhancing ecosystem services" [19] (p. 2). But the term is used equivocally and is applied to diverse contexts and farming systems:

"Aspects of agroecological and conventional intensification can be implemented in concert: agroecological principles can be applied to modify high-input, high-technology systems, while modern mechanization, improved seeds, and fertilizers are incorporated into some agroecological systems. This hybrid or 'consider all options' approach has been endorsed by major global reports [8,20,21], which have advocated the use of ecologically based farming methods without excluding chemical inputs, hybrid seeds, or other management tools" [19] (pp. 2-3).

We agree [14] (p. 356) that these terms are "often weakly and narrowly defined, and lack engagement with key principles of sustainability." This is also the case of the term agroecological intensification whose supporters claim that "food production can increase and at the same time be sustainable through the ecological intensification of current agriculture, making intensive and smart use of the natural functionalities that ecosystems offer" [22] (p. 11). Nothing is said about how the increase in food production will be maintained in the long term. Used in such an ambiguous manner, these terms can also become a way of greening conventional agriculture.

Our thesis is that "sustainable intensification" and "ecological intensification" are contradictions in terms, since they have no thermodynamic foundation. Intensification cannot be maintained indefinitely in a finite, closed world and is not, therefore, sustainable. But in a specific place and over a limited period of time it could be sustainable if the intensification occurs under agroecological criteria. Indeed, agroecology holds that the only sustainable way to further intensify agricultural production without damaging the natural resources is by using agroecological methods [23-25]; for example, by crop rotation, increasing biodiversity, incorporating legumes into fields, using agroforestry techniques, etc. This could be the best way to reduce the yield gap that exists today between conventional agriculture and OF. This gap weakens the possibility of OF becoming a real alternative to conventional production on the horizon of 2050. In other words, only OF managed with agroecological criteria could meet the future food challenges sustainably, though, of course, for a limited period of time, not indefinitely.

This paper supports this thesis through the study of Spanish agriculture. The text is divided into two sections. In the first, we explore theoretically the possibility of raising agricultural production without degrading natural resources. The approach taken is strictly biophysical, leaving aside aspects of economic viability and social equity, which are equally essential for sustainability. The second section shows the real possibilities of intensifying Spanish agricultural production. Indeed, the study concludes that the only sustainable solution is through the agroecological management of Spanish agroecosystems. Some conclusions are drawn from this study that are relevant both for the ongoing debate on ecological intensification and organic production and for the development of agroecology itself.

\section{Ecological Intensification from an Agroecological Perspective}

To address the possibilities of intensification rigorously, it is essential to understand the functioning of agricultural systems from a biophysical perspective. Only in this way could we examine the real possibility of sustainable intensification.

\subsection{Sustainability in Agroecosystems}

According to Georgescu-Roegen [26], the ultimate aim of agrarian activity is not the production of useful biomass, but the reproduction of the fund elements required to produce it. So an agroecosystem could be considered sustainable to the extent that its biophysical fund elements are adequately reproduced by means of adequate quantitative and qualitative flows of energy and material. Fund reproduction requires a certain amount of energy in the form of biomass which must be provided in each productive process (see Figure 1). The energy required can only be replaced by external energy to a very small extent, given its varying nature. Within the agroecosystem, for example, the food chains which sustain both life in the soil and biodiversity in general within the agroecosystem can only be fed with biomass. Substitution may allow the system to function, with a certain increase in total 
entropy and increasing biomass intended for society, but this may be at the cost of not reproducing fund elements and, therefore, reducing the sustainability of the agroecosystem.
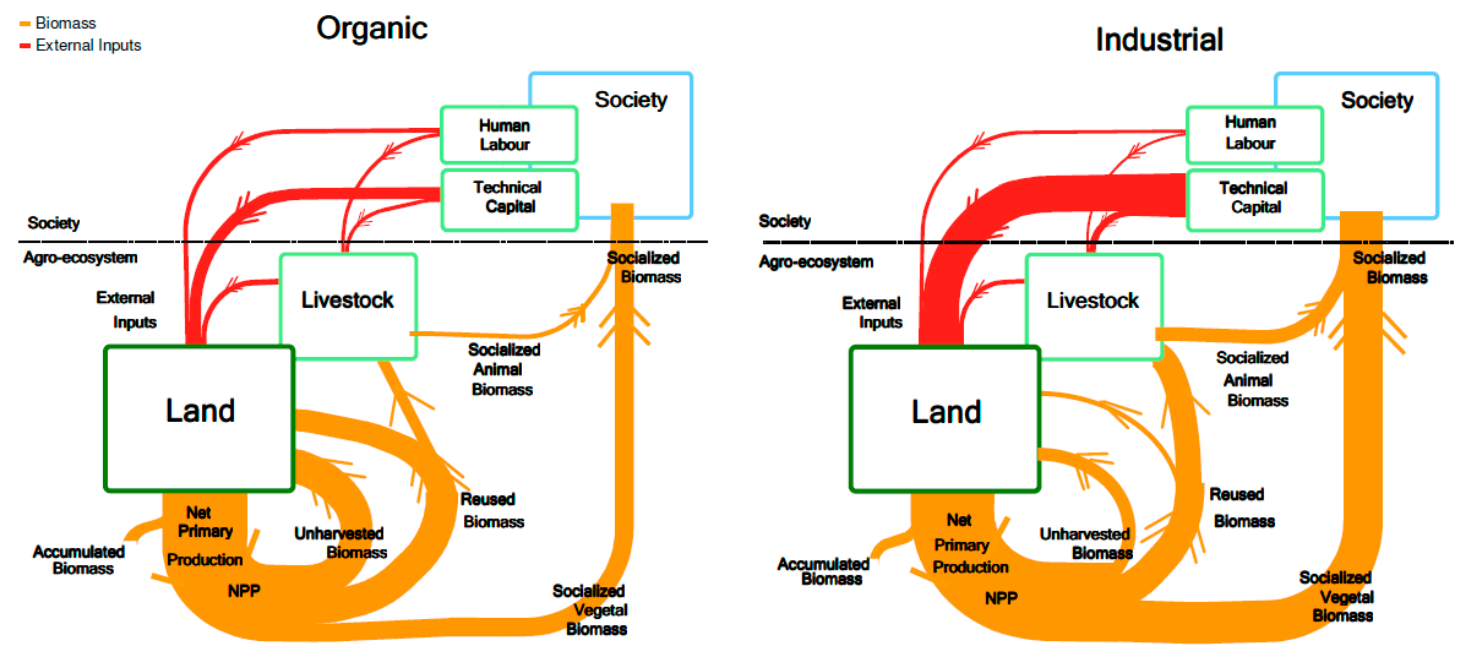

Figure 1. Energy flows in agro-ecosystems in organic and industrial management.

This is because agroecosystems work as living beings. Mae-Wan Ho [27] long ago suggested that an ecosystem is more sustainable when it maximizes cyclical or circular flows of energy and minimizes dissipative flows. These circular flows increase the capacity to store energy and, therefore, the efficiency of energy use and space-time differentiation, expressed in levels of biodiversity. That is, minimizing the production of entropy. These cycles allow the entropy generated in one part of the ecosystem to be compensated by the negative entropy generated in another over a certain period of time. The same is true for agroecosystems. As is well known, the sustainable management of an agroecosystem depends on its level of biodiversity, its wealth of organic matter, its appropriate replenishment of soil fertility, etc., closing biogeochemical cycles on a local scale. This means that a significant part of the biomass generated must recirculate in order to perform the basic productive and reproductive functions of the agroecosystem: seeds, animal labor, soil organic matter, functional biodiversity, etc. In accordance with the proposals of Ho and Ulanowicz [28] and later of Ho [29], the sustainability of agroecosystems, therefore, correlates positively with the quantity and quality of its internal loops or cycles and, to that extent, with the energy flows which circulate within it and whose function is to reproduce the fund elements.

To this extent, an agroecosystem with fund elements which require the dissipation of low levels of energy for its maintenance and reproduction by means of those recirculation processes in turn generates low entropy in its environment and minimizes the flows of external energy. In effect, if the low-entropy energy required for the functioning of the system is provided by the available internal loops, external energy requirements will be lower and total entropy will fall. In contrast, when the internal complexity of an agroecosystem is substantially reduced, and its internal loops diminished, it needs to generate internal order by importing significant amounts of energy. In these cases, total entropy also increases significantly, and we find before a high-entropy agroecosystem whose sustainability is seriously compromised.

In other words, the energy flows which enter agroecosystems are directly proportional to the degree of human intervention in those systems. When the intervention is minimal and generally respects the dynamics and functioning of the ecosystems (with a high density of internal loops), the imported or external flow of energy is also minimal. At the other extreme, when a complex ecosystem is simplified to the point that it hosts a monoculture, external energy flows must be increased significantly [21] (p. 276). This means that the capacity of the agroecosystem to maintain the 
production of biomass in the long term, without increasing inputs of external energy, is the foremost expression of sustainable management [30].

\subsection{Sustainability and Its Land Cost}

All production of biomass has a cost in terms of territory since the capture of incident solar energy by biological converters (photosynthesis) requires an area of land. This cost has two components, one quantitative and the other qualitative. The quantitative dimension offers information regarding the amount of land needed to produce a specific quantity of biomass, depending on the edaphic, climatic and technological conditions at the time (land requirement), whereas the qualitative dimension (land functionality) refers to the way in which that amount of land should be organized. It is not enough to simply have a certain amount of land; it is essential to give it structure, organizing the different components so that they fulfil their tasks. Each metabolic arrangement configures a particular landscape structure which conditions the ecological processes (energy and material flows, natural population regulation, etc.) in the agroecosystem. Landscape ecologists have used the term 'functional landscape' to summarize the effects of landscape structure (spatial and temporal configuration) on ecological processes [31-33]. So the functional land of (or forming part of) an agroecosystem is that which possesses the necessary structure to sustain ecological processes (energy and material flows, and regulation of pests and diseases), within appropriate limits of variability. Thus high levels of resilience and acceptable levels of productivity to the whole agroecosystem are achieved, giving it sustainability. These two dimensions of the land cost are related to the quantity and quality of internal loops (if they are of high or low entropy).

In accordance with this, each specific arrangement of the agroecosystem has a cost in terms of the territory (housing internal loops), depending on the complexity and connectivity of the energy flows which maintain and reproduce its fund elements, that is, the complexity and connectivity of its internal loops. To that extent, each specific arrangement of the agroecosystem is reflected in a specific organization of the landscape, imposing its particular footprint on the territory [34,35]. For example, in organic or agrarian metabolic regimes [36,37], agroecosystems function in an integrated manner in such a way that the internal loops clearly extend beyond the cultivated land and cover wide stretches of the territory. The land cost is higher when the energy and material flows come from internal net primary productivity, something which used to occur in traditional farming and occurs partially today in OF. As domestic flows of energy and materials have been gradually replaced by imported flows, the land cost of modern farming has been reduced.

Industrialized or conventional agriculture has made savings in terms of land due to the injection of growing quantities of energy and nutrients from fossil and mineral sources, mainly brought in from outside the agroecosystems. The integration of forestland, pastureland and diverse agricultural uses, which in the past ensured the diversity required for the stability of agroecosystems, has been lost and, moreover, many uses of the land have been sacrificed to expand monocultures or to use the land exclusively for livestock. Agrarian diversity has deteriorated significantly. In this regard, the landscapes of industrialized agriculture are simplified to the same extent that the internal loops within their agroecosystems are reduced. They are, therefore, high-entropy dissipative structures. The result is a considerable loss of sustainability.

The territorial arrangement of solar-energy-based agriculture has changed over time and its land cost has been modified as a function of numerous variables (the supply of land, available technology, the requirements of the population, etc.). A better design of the internal loops in an agroecosystem can appreciably reduce the land cost that all biomass production involves, generating more biomass at a minimum cost in terms of territory. A clear example of this are the polycultures developed by traditional agriculture, whose success was based precisely on their ability to host ecological processes, reducing the land cost (Land Equivalent Ratio, LER) [23,38]. They are a good example of low-entropy internal loops. This is due to the fact that the relationship between the two dimensions of land cost or biomass production - its land requirement and its land functionality-is not necessarily a direct one. 
When land takes on ecological functions, there is not always a parallel increase in land cost. With the correct management of agroecosystems, the land can perform the same functions, or more, without increasing the land cost. This has occurred on occasions in traditional agriculture [34] and currently occurs partially in organic production [35].

It should be noted that the reconstruction of the internal loops of agroecosystems, which is the way to make agricultural production more sustainable, requires the replacement of fossil fuels by biomass and, therefore, a further increase in land costs. Indeed, ecological intensification should imply increasing net primary production as a whole. It is essential to raise not only the total amount of biomass to increase the supply of food and raw materials for society, but also to increase the recycled biomass (reused and unharvested biomass), essential for reproducing the fund elements. To make this possible, more land is needed to "produce" more manure and organic matter, more biomass to sustain biodiversity-supporting food chains and fix nitrogen, and more water for irrigation. More intensive cultivation also needs more energy carriers to fuel machines, that is to say, additional land to produce biofuels.

Agroecological management can certainly reduce the land cost of sustainability by, for example, introducing renewable energy and intensifying the number and connectivity of the internal loops of agroecosystems with better landscape design. But in any event, ecological intensification involves the occupation of additional amounts of land and fresh water that, by nature, are limited. Although this may be possible in some cases on a local or regional scale, it will be much more difficult on a global scale since the expansion of arable land and consumption of fresh water are close to their limits, as has been stated by the FAO [20]. There is only room for temporary ecological or agroecological intensification based on organic production, but not on conventional production.

Let us explain this. Conventional agriculture is unsustainable because it is unable to reproduce the fund elements of agroecosystems and cannot, therefore, be the solution for the 2050 horizon. As is well known, large tracts of land all over the planet have suffered severe degradation processes due to nutrient mining, erosion and salinization. It is also well known that constant impoverishment of organic matter in soil has been experienced by land under industrial agriculture for a long time. This scarcity of organic matter, the "conventionalization" process and the lack of training in organic management are the factors which explain the yield gap between conventional and organic production. Both degraded land and current OF practices can only recover their optimal production levels or overcome the yield gap with proper agroecological management. This management may lead to a temporary process of intensification until a stable state has been reached. Only the promotion of OF managed in an agroecological way makes temporary sustainable intensification possible. In short, from an agroecological point of view, ecological intensification is justified in two circumstances: for recovering or restoring degraded lands, for example in many African countries, and for overcoming the current yield gap that characterizes OF.

\section{Methodology}

\subsection{Data Collection}

The study quantifies the land cost of the transformation of Spanish agriculture and livestock farming to organic production, considering that the Spanish territory would provide the nitrogen flows and functional biodiversity necessary to allow the functioning of the agroecosystems. The crops not devoted to food production would be excluded from the conversion, since they do not contribute to diet and there is no comparative data available for organic versus non-organic production. The excluded crop area (textile fiber, tobacco, ornamental plants and other crops) represents less than $0.6 \%$ of total agricultural land [39].

The baseline year chosen for the comparison was 2008, for two reasons. Firstly, there is a comparative study of Spanish organic and conventional agriculture for that year [40,41]. In this study, the management practices of organic and conventional crops were obtained via personal interviews, 
in order to gather detailed information on management techniques and inputs used. Valid information was obtained for 80 organic and 80 conventional agricultural systems, although two outliers from each were eliminated.

Comparisons were made between the same crops grown using organic and conventional methods. To minimize possible differences due to external factors unrelated to land management practices, a number of prerequisites were established, which had to be met by the farms and crops under study:

a. The organic farms had full certification for the sale of organic products, a prerequisite based on the argument that during their conversion period, these growers will have acquired expertise and will therefore have refined their organic practices to achieve a certain degree of stability.

b. The organic and conventional farms compared were close to each other (preferably adjoining), thus avoiding possible differences in factors such as soil type, aspect and topography.

c. The pairs of organic and conventional crops to be compared were the same or similar in terms of the varieties used, production cycles (planting and harvesting calendar), production system (i.e., open air, greenhouse, tunnel, irrigation systems), training systems (i.e., same plant stocks, trellises, free-form) and type of end product (i.e., fresh, canned, juice).

We also verified that the practices used by the conventional farmers interviewed were representative of the conventional sector as a whole. To do so, the average dose of $\mathrm{N}$ applied as a chemical fertilizer in each group of crops was multiplied by the number of hectares they occupied in 2008. A total consumption of $691,446 \mathrm{t}$ of $\mathrm{N}$ was obtained. This amount is $93.5 \%$ of the industrially synthesized $\mathrm{N}$ consumed in the Spanish agrarian sector in $2008(739,757 \mathrm{t})$ [42]. This latter figure includes the fertilizer applied to pastureland and non-food crops, which represent at least $2.4 \%$ of total fertilization [43]. Therefore, the practices of the conventional farmers interviewed are representative of conventional farming.

The second reason for choosing the year 2008 was to avoid the study being affected by changes in farming practices caused by the economic crisis in Spain (e.g., reduction in the use of inputs).

In the two scenarios contemplated (see next section), the land cost calculated for each group of crops was multiplied by the total area occupied by those crops in 2008 [39].

\subsection{Scenarios for the Evaluation of the Land Cost of Organic and Conventional Farming}

The land cost of organic and conventional farming was evaluated in two different scenarios.

Scenario 1. Land cost of conversion of Spanish farming to extensive Organic Farming

In this scenario, all conventional Spanish agriculture is transformed to organic farming, strictly adopting the farming practices and yields of organic farming in 2008 [40,41]. In that year, organic farming in Spain occupied 1,129,844 ha (excluding forestland, 4.8\% of the Useful Agricultural Area) and, as we shall see, it was clearly extensive in nature. It is an agricultural practice that uses very little fertilizer and whose yield is significantly lower than conventional agriculture, particularly in those groups of crops which are usually farmed more intensively (e.g., irrigated crops). The land cost of expanding OF practices to the whole of Spanish agriculture was calculated.

Scenario 2. Land cost of conversion of Spanish farming to intensive Organic Farming

This scenario is based on the previous one and seeks to model the land cost of intensive organic farming, based on low-entropy internal loops [30]. This requires practices such as the sowing of green legume manure and the use of agroindustrial waste as fertilizer to be prioritized. As a complement, it supposes the development of integrated crop/livestock systems, where animals are fed hay, grain and by-products from food production, and provide manure for the most demanding crops. It would be, then, a scenario constructed under agroecological criteria on the basis of the real scenario (Scenario 1). Firstly, it explores the possibility of increasing yield while minimizing the land 
cost of the sustainable functioning of agroecosystems [35]. Secondly, it identifies the limits of organic intensification. Depending on the contribution of green manure versus animal manure in this strategy, Scenario 2 is divided between (a) (a greater contribution of manure for nitrogen fertilization) and (b) (a greater contribution by green manure).

\subsection{Assessment of Land Cost}

The land calculation was based on the following factors:

a. Yield. To calculate the difference in land needed to produce the same quantity of production, a value of " 1 " was given to the crops with conventional management and the ratio obtained by dividing conventional yield by organic yield was the value given to the organic crops.

b. Management of pests and diseases. The land cost associated with pest and disease control has two parts: (1) the part derived from the manufacturing process of the pesticides used; (2) the part which is incurred to generate functional biodiversity which aids in supporting natural enemies, thus increasing the resilience of the agroecosystem. The first component was given a value of zero, given the insignificant amount of land used by the pesticide industry, whether the products are chemically synthesized or of biological origin.

The second component is more difficult to value, since land occupation varies according to the farmer's strategy for the introduction of functional biodiversity. Planting hedges and woodland islets or the maintenance of non-cultivated land on the farm occupy territory. Other strategies, such as maintaining natural cover crops in fruit orchards, do not. The introduction of biodiversity by means of intercropping also often allows land saving $[23,38]$.

In this paper, it has been considered, with a certain degree of arbitrariness, that the introduction of functional biodiversity in Spanish organic farming would suppose a cost of $5 \%$ of farmland. This percentage is similar to that obtained in different case studies of pest management under Mediterranean agroclimatic conditions [44,45]. The planting of the equivalent of a $100 \mathrm{~m}$ by $5 \mathrm{~m}$ hedge per agricultural hectare is very ambitious in Spain, given the scarcity of areas of natural vegetation in these zones.

c. Irrigation. This is usually localized drip irrigation and uses water pumped from the aquifer. The land cost is due mainly to the water reservoirs, which occupy relatively little land in comparison with the hectares of irrigated crops. Furthermore, there are no differences in irrigation methods between organic and conventional farms. This has therefore not been taken into consideration in the land cost calculation.

d. Mechanical labor. At present, the tasks performed in OF use the same technology as in conventional farming, and involve considerable fossil energy costs, but little in terms of land cost. For this reason, the land cost of mechanical labor has not been taken into account.

e. Organic fertilization. The manufacture of chemical fertilizers can have a significant impact at local level. However, the land cost is insignificant when evenly distributed per chemically fertilized hectare at worldwide level. For this reason, it is considered of zero value for the purposes of this study. However, organic fertilization does occupy a large amount of land due to the use of green manures and animal manure $[34,35]$. Organic farming uses nitrogen of strictly organic origin. However, for the input of phosphorus and potassium, organic farmers can complement organic fertilizers with mineral fertilizers, obtained through mechanical procedures from rocks rich in these macronutrients. Therefore, since nitrogen is the only macronutrient whose replacement depends exclusively on organic fertilizers, the calculation of the land cost of organic fertilization concentrates on this element.

A land cost of between 9 and $15 \mathrm{~m}^{2}$ was estimated per kilogram of $\mathrm{N}$ which enters symbiotically into fruit crops by sowing vetch between the rows. In the case of arable crops, the land cost due to seed use varies between 6 and $17 \mathrm{~m}^{2} \cdot \mathrm{kg}^{-1} \mathrm{~N}$ for irrigation and dry farming, respectively, and rises to $32-154 \mathrm{~m}^{2} \cdot \mathrm{kg}^{-1} \mathrm{~N}$ when the reduction of the intensity of rotation is also taken into consideration. The land cost of each $\mathrm{kg}$ of $\mathrm{N}$ added in the form of animal manure would be $245 \mathrm{~m}^{2} \cdot \mathrm{kg}^{-1} \mathrm{~N}$ (calculated from [46-48]) (see Tables S1-S3, Supplementary Materials). 
The N content of the useful manure produced in Spain (2008) by livestock that was fed on own resources was also estimated: grain, straw and forage [39] and agroindustrial byproducts [49]. It is necessary to calculate the animal manure in order to discount it from the total requirements of the different scenarios, since it does not generate any extra land cost, as it is included in the baseline territorial structure of Spanish agriculture (Table S4, Supplementary Materials).

The $\mathrm{N}$ content of useful manure originating from the foodstuffs produced and fed to livestock in Spain in 2008 and which, therefore, does not generate any extra land cost, came to 260,956 t N.

\section{Results}

\subsection{Scenario 1. Land Cost of Conversion of the Spanish Agriculture to Extensive Organic Farming}

The yield of Spanish organic farming is $23 \%$ lower than the yield of conventional production and generates a high land cost (Table 1$)$. The reduction in yield is lower $(<10 \%)$ in permanent crops which are better adapted to the Mediterranean climate (olive trees, vines and other dry farming fruit crops), it is intermediate for horticultural crops (approximately 25\%) and very high in herbaceous crops and irrigated fruit crops (up to $40 \%$ ). In these latter cases, significant problems were detected both as regards fertilization and weed control in herbaceous crops, and pest damage in fruit crops. For many organic crops, the dose of nitrogen received was less than $60 \%$ of that received under conventional agriculture (Table 2). Undoubtedly, this gap in nitrogen fertilization is a key to the significant reduction in yield observed.

Currently, the land cost of fertilization with green manure is minimal (Table 1), since this technique is used little by Spanish organic farmers. Table 3 shows the total amount of nitrogen that would be necessary to provide in the form of animal manure on Spanish crops using the organic farming techniques of 2008. It takes into account not only the real crop area in 2008, but also the extra land that would be necessary in order to compensate the fall in production with respect to conventional agriculture. It also includes the crop area devoted to the production of seed for green manure. The nitrogen required would be $436,883 \mathrm{t}$. After discounting the contribution made by livestock with the national resources existing in $2008(260,956 \mathrm{t} \mathrm{N})$, there would be a deficit of 175,927 $\mathrm{t} \mathrm{N}$ which would have to be produced in 4.3 Mha of extra land devoted to the production of organic barley vetch (Figure 2). The land unit cost of organic fertilization through the use of animal manure is shown in Table 1. It can be seen that, for the majority of crops, the use of animal manure is the main contributor to the land cost, standing out for its contribution in relative terms in the case of vegetables $(>80 \%)$. Only in the case of winter cereals, pulses, fodder and industrial crops is its contribution lower than $40 \%$, specifically, $18 \%$. In this group of crops, the land cost is due mainly to the fall in yield (76\%).

Figure 2 shows the increase in the total crop area that would be necessary and the changes in the orientation of production that would be required. The crop area would have to grow to 20 Mha (2.7 million more than the area available in 2008), fallow land would disappear and the extra crop area devoted to ecological infrastructure would approach a million hectares. This latter component would, undoubtedly, improve the landscape and connectivity with areas of natural vegetation. As regards the orientation of production, the largest growth would be seen in winter herbaceous crops (including barley), which would multiply the current crop area by 1.5 . 
Table 1. Unit Land Cost due to yield gap, introduction of functional biodiversity, planting of legume green manure and manure use in actual organic scenario (Organic Scenario 1).

\begin{tabular}{|c|c|c|c|c|c|c|c|}
\hline & $\begin{array}{c}\text { Organic Yield/ } \\
\text { Conventional Yield }\end{array}$ & $\begin{array}{l}\text { Land Cost for } \\
\text { Yield Gap * } \\
\text { (ha) (A) }\end{array}$ & $\begin{array}{c}\text { Land Cost of } \\
\text { Functional } \\
\text { Biodiversity * (ha) (B) }\end{array}$ & $\begin{array}{c}\text { Green } \\
\text { Manure-Covered } \\
\text { Surface (\%) }\end{array}$ & $\begin{array}{l}\text { Land Cost for } \\
\text { Green Manure * } \\
\text { (ha) (C) }\end{array}$ & $\begin{array}{c}\text { Land Cost for } \\
\text { Manure * (ha) (D) }\end{array}$ & $\begin{array}{l}\text { Total Unit Land } \\
\text { Cost* (ha) } \\
(\mathrm{A}+\mathrm{B}+\mathrm{C}+\mathrm{D})\end{array}$ \\
\hline $\begin{array}{l}\text { Winter cereals, pulses, } \\
\text { fodder and industrial crops }\end{array}$ & 0.63 & 0.60 & 0.05 & 0 & 0 & 0.141 & 0.791 \\
\hline $\begin{array}{c}\text { Summer cereals, } \\
\text { sugar beet and sugarcane }\end{array}$ & 0.69 & 0.45 & 0.05 & 0 & 0 & 1.241 & 1.741 \\
\hline Open-air vegetables & 0.75 & 0.34 & 0.05 & 0 & 0 & 2.092 & 2.482 \\
\hline Greenhouse vegetables & 0.72 & 0.38 & 0.05 & 0 & 0 & 1.694 & 2.124 \\
\hline Vineyards & 0.91 & 0.10 & 0.05 & 5 & 0.004 & 0.146 & 0.300 \\
\hline Irrigated fruit trees & 0.60 & 0.66 & 0.05 & 35 & 0.031 & 1.930 & 2.671 \\
\hline Rainfed fruit trees & 0.91 & 0.10 & 0.05 & 0 & 0 & 0.098 & 0.248 \\
\hline
\end{tabular}

Table 2. Average rate of nitrogen $(\mathrm{N})$ application by organic and conventional farmers interviewed $\left(\mathrm{kg} \cdot \mathrm{ha}^{-1}\right)$.

\begin{tabular}{cccc}
\hline & \multicolumn{2}{c}{$\mathbf{N}$ (kg/ha) } \\
\cline { 2 - 4 } & Organic & Conventional & \% Organic/Conventional \\
\hline Winter cereals, pulses, fodder and industrial crops (excluding barley) & 10 & 48 & $20 \%$ \\
Summer cereals, sugar beet and sugarcane & 87 & 152 & $57 \%$ \\
Open-air vegetables & 159 & 124 & $128 \%$ \\
Greenhouse vegetables & 124 & $43 \%$ \\
Olives & 29 & $43 \%$ \\
Vineyards & 13 & 67 & $166 \%$ \\
Irrigated fruit trees & 118 & 8 & $57 \%$ \\
Rainfed fruit trees & 9 & 207 & $22 \%$ \\
\hline
\end{tabular}


Table 3. Nitrogen total need from manure (t), including that applied in the extra territory needed to compensate the yield gap and to produce the green manure seed (Organic Scenario 1).

\begin{tabular}{|c|c|c|c|c|c|c|}
\hline & $\begin{array}{l}\text { Current Surface } \\
\text { (ha) }\end{array}$ & $\begin{array}{l}\text { Total Land Cost by } \\
\text { Yield Gap (A) (ha) }\end{array}$ & $\begin{array}{l}\text { Total Land Cost by } \\
\text { Green Manure (B) (ha) }\end{array}$ & $\begin{array}{l}\text { Area with Manure } \\
\text { Need (A + B) (ha) }\end{array}$ & $\begin{array}{l}\text { N Applied from } \\
\text { Manure (kg/ha) }\end{array}$ & $\begin{array}{c}\text { Total N Need } \\
\text { from Manure (t) }\end{array}$ \\
\hline Winter cereals, pulses, fodder and industrial crops (excluding barley) & $4,703,845$ & $7,507,349$ & 87,948 & $7,595,297$ & 10 & 73,150 \\
\hline Summer cereals, sugar beet and sugarcane & 519,526 & 754,151 & 0 & 754,151 & 87 & 65,410 \\
\hline Open-air vegetables & 373,551 & 499,191 & 0 & 499,191 & 159 & 79,287 \\
\hline Greenhouse vegetables & 70,743 & 97,693 & 0 & 97,693 & 124 & 12,157 \\
\hline Olive groves & $2,450,471$ & $2,546,899$ & 0 & $2,546,899$ & 29 & 73,680 \\
\hline Vineyards & $1,109,049$ & $1,221,323$ & 0 & 1221,323 & 13 & 16,436 \\
\hline Irrigated fruit trees & 562,000 & 932,240 & 0 & 932,240 & 118 & 110,060 \\
\hline Rainfed fruit trees & 674,929 & 744,337 & 0 & 744,337 & 9 & 6704 \\
\hline Total & & & & & & 436,883 \\
\hline
\end{tabular}

Source: N applied: farmer interviews. Current surface (MAGRAMA, 2009).

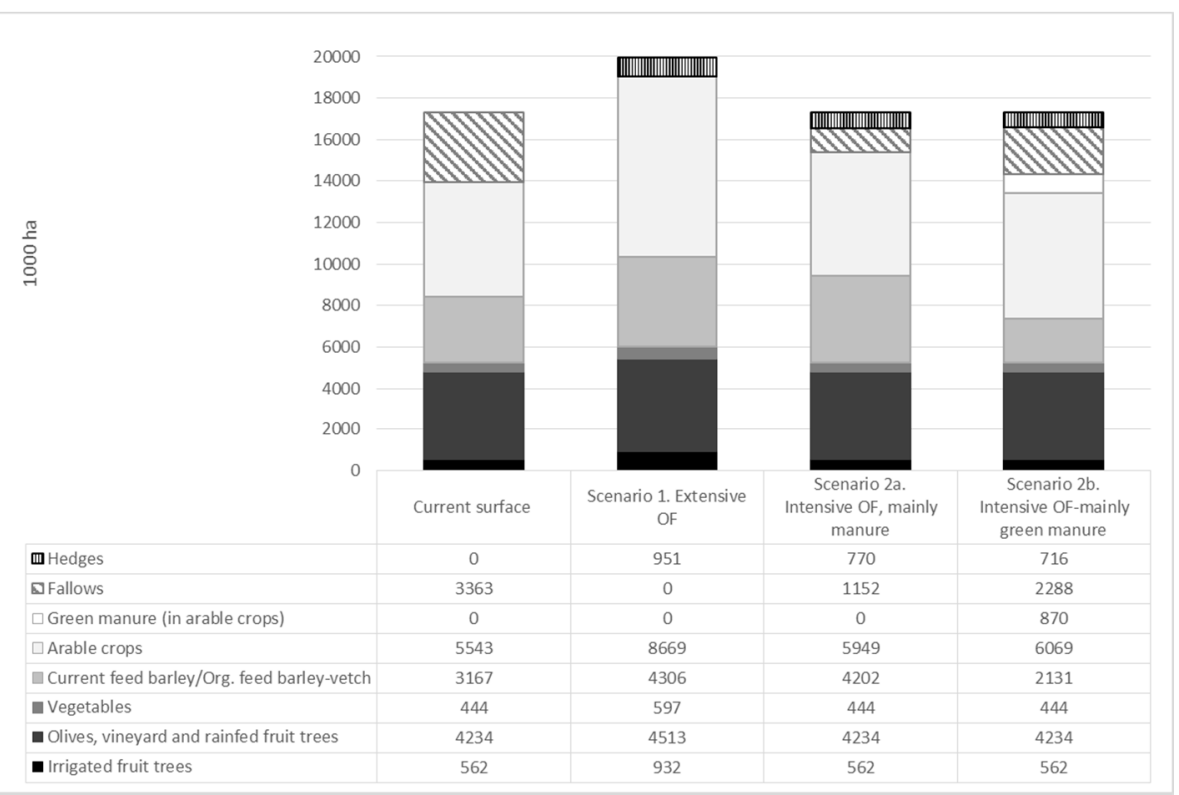

Figure 2. Cropland distribution at present and in different organic scenarios by crops (excluding 80,924 ha of non-food crops). 


\subsection{Scenario 2. Land Cost of the Conversion of Spanish Agriculture to Intensive Organic Farming Based on} Low-Entropy Internal Loops

Adjusting Scenario 1 to the agricultural crop area available in 2008, (17.4 Mha), would mean a fall in Spanish agricultural production of almost 13\%. Therefore, it is necessary to find means of intensification that diminish the land cost of the transformation to organic farming. As stated in the introduction, intensifying means reducing the yield gap between conventional and organic production. The question is whether it is possible to reduce that gap without dramatically increasing the land cost.

This gap is partially attributable to aspects which can be improved without consuming more land. Explicitly, we refer to techniques which reduce losses caused by pests and weeds. It is difficult to ascertain by what percentage better management could reduce the gap. Nevertheless, it can be assumed that, in the case of vine cultivation and open-air horticultural produce, the yield gap is not due to a lack of fertilizer (Table 2) and adequate management could bring the yields achieved by conventional production without any extra land cost. Nevertheless, in other crops, the sharp reduction of nitrogen fertilizers could effectively contribute to a fall in the yield of OF.

As stated in the section on Methodology, the initial land cost of $1 \mathrm{~kg}$ of nitrogen differs, depending on the means used: legume green manure versus animal manure, and the orientation of production (arable versus permanent crops). In Scenario 2, the most economic strategy in terms of land investment was adopted whenever possible. Therefore, it was assumed that legume green manure was used by $100 \%$ of the farmers on fruit crops. This technique guarantees the correct nitrogen fertilization of the olive, grapevine and nuts, which could reach $100 \%$ of conventional production at a small land cost (Table 4). In the case of irrigated fruit crops, this would require a complement through the addition of animal manure, since the $\mathrm{N}$ fixed by the legume green manure ( $97 \mathrm{~kg} \mathrm{~N} / \mathrm{ha}$ ) (Table S3, Supplementary Materials) would not close the gap with conventional methods (Table 2). Taking this into account, after the generalization of the use of legume green manure on fruit crops, a calculation was made of the total amount of $\mathrm{N}$ required in order for organic fertilization to equal conventional fertilization, including that applied on the extra land required to produce the seed for the green manure (Table 5).

This $\mathrm{N}$ deficit can be palliated through the return of the greater part of agroindustrial waste which is not used for animal feed, specifically the waste from oil and wine production, with its $\mathrm{N}$ content of 22,228 t (Table S5, Supplementary Materials). The recycling and use of agroindustrial waste as fertilizer is an OF strategy, little used today, that could be considered a low-entropy internal loop with an insignificant land cost. It is, therefore, a very appropriate strategy for the intensification of organic farming from an agroecological perspective.

As in the case of Scenario 1, the N supplied by the manure of livestock fed on grain, straw, forage and agroindustrial byproducts produced in $2008(260,956 \mathrm{t} \mathrm{N})$ must be discounted.

Having taken into account green manure on fruit crops, the recycling of the byproducts of agroindustry and the manure of livestock fed by Spanish agricultural land in 2008, there is a deficit of $171,705 \mathrm{t}$ of $\mathrm{N}$. Two strategies are possible to palliate this deficit: to provide this nitrogen solely from animal manure or reduce manure use to the minimum (in irrigated fruit orchards) and increase the use of green manure on arable crops. The land cost if only animal manure were used would come to 4.2 Mha (Scenario 2a). However, with the second strategy, extending green manure use to arable crops, the land cost would be reduced to 3.0 Mha (Scenario $2 b$ ). In this case, the $\mathrm{N}$ deficit would grow slightly $(177,479 \mathrm{t} \mathrm{N})$, due to the enlargement of the land area devoted to green manure, which would rise from 405,826 ha to 525,274 ha, an increase of $29 \%$ (Table 5). 
Table 4. Unit Land Cost due to yield gap, introduction of functional biodiversity, planting of legume green manure and manure use in intensive organic scenario (Organic Scenario 2a and 2b).

\begin{tabular}{|c|c|c|c|c|c|c|c|}
\hline & $\begin{array}{l}\text { Land Cost for } \\
\text { Yield Gap * } \\
\text { (ha) (A) }\end{array}$ & $\begin{array}{l}\text { Land Cost of } \\
\text { Functional } \\
\text { Biodiversity * } \\
\text { (ha) (B) }\end{array}$ & $\begin{array}{c}\text { Land Cost for } \\
\text { Green Manure } \\
\text { (in Fruit Orchard) * } \\
\text { (ha) (C) }\end{array}$ & $\begin{array}{c}\text { Land Cost for } \\
\text { Manure * Scenario } \\
\text { 2a (ha) (D) }\end{array}$ & $\begin{array}{c}\text { Land Cost for } \\
\text { Organic } \\
\text { Fertilization * } \\
\text { Scenario } 2 b(h a)\left(D^{\prime}\right)\end{array}$ & $\begin{array}{l}\text { Total Unit Land Cost * } \\
\text { Scenario 2a } \\
\text { (ha) }(A+B+C+D)\end{array}$ & $\begin{array}{c}\text { Total Unit Land Cost } \\
\text { Scenario } 2 b \\
\text { (ha) }\left(\mathrm{A}+\mathrm{B}+\mathrm{C}+\mathrm{D}^{\prime}\right)\end{array}$ \\
\hline $\begin{array}{c}\text { Winter cereals, pulses, } \\
\text { fodder and industrial crops }\end{array}$ & 0 & 0.05 & 0 & 0.420 & 0.297 & 0.470 & 0.347 \\
\hline $\begin{array}{l}\text { Summer cereals, sugar beet } \\
\text { and sugarcane }\end{array}$ & 0 & 0.05 & 0 & 1.407 & 0.992 & 1.457 & 1.042 \\
\hline Open-air vegetables & 0 & 0.05 & 0 & 1.146 & 0.808 & 1.196 & 0.858 \\
\hline Greenhouse vegetables & 0 & 0.05 & 0 & 2.705 & 1.907 & 2.755 & 1.957 \\
\hline Olive groves & 0 & 0.05 & 0.088 & 0.000 & 0.000 & 0.138 & 0.138 \\
\hline Vineyards & 0 & 0.05 & 0.075 & 0.000 & 0.000 & 0.125 & 0.125 \\
\hline Irrigated fruit trees & 0 & 0.05 & 0.088 & 1.014 & 0.715 & 1.152 & 0.853 \\
\hline Rainfed fruit trees & 0 & 0.05 & 0.088 & 0.000 & 0.000 & 0.138 & 0.138 \\
\hline
\end{tabular}

Table 5. Nitrogen total need $(\mathrm{t})$, including that applied in the extra territory needed to produce the green manure seed (Organic Scenario $2 \mathrm{a}$ and $2 \mathrm{~b}$ ).

\begin{tabular}{|c|c|c|c|c|c|c|c|c|}
\hline & \multirow{2}{*}{$\begin{array}{l}\text { Current } \\
\text { Surface (ha) }\end{array}$} & \multicolumn{2}{|c|}{ Total Land Cost by Green Manure (ha) } & \multicolumn{2}{|c|}{ Area with N Need (ha) } & \multirow{2}{*}{ N Need (kg/ha) } & \multicolumn{2}{|c|}{ Total N Need (t) } \\
\hline & & Scenario 2a & Scenario $2 \mathbf{b}$ & Scenario 2a & Scenario $2 \mathbf{b}$ & & Scenario 2a & Scenario $2 b$ \\
\hline $\begin{array}{l}\text { Winter cereals, pulses, fodder and } \\
\text { industrial crops (excluding barley) }\end{array}$ & $4,703,845$ & 405,826 & 525,274 & $5,109,671$ & $5,229,119$ & 48 & 247,016 & 252,791 \\
\hline $\begin{array}{c}\text { Summer cereals, } \\
\text { sugar beet and sugarcane }\end{array}$ & 519,526 & 0 & 0 & 519,526 & 519,526 & 152 & 79,141 & 79,141 \\
\hline Open-air vegetables & 373,551 & 0 & 0 & 373,551 & 373,551 & 124 & 46,352 & 46,352 \\
\hline Greenhouse vegetables & 70,743 & 0 & 0 & 70,743 & 70,743 & 293 & 20,712 & 20,712 \\
\hline Olive groves & $2,450,471$ & 0 & 0 & $2,450,471$ & $2,450,471$ & 0 & 0 & 0 \\
\hline Vineyards & $1,109,049$ & 0 & 0 & $1,109,049$ & $1,109,049$ & 0 & 0 & 0 \\
\hline Irrigated fruit trees & 562,000 & 0 & 0 & 562,000 & 562,000 & 110 & 61,668 & 61,668 \\
\hline Rainfed fruit trees & 674,929 & 0 & 0 & 674,929 & 674,929 & 0 & 0 & 0 \\
\hline Total & & & & & & & 454,889 & 460,663 \\
\hline
\end{tabular}


Figure 2 shows that the conversion of Spanish agriculture to intensive organic methods is possible, based on low-entropy internal loops. In Scenario 2, it would not be necessary to increase the agricultural crop area, but changes in the orientation of production would be required. In Scenario 2a, fallow land would be reduced to 2.2 Mha, which would be used for feed barley and hay vetch (1 Mha), arable crops (green manure seed production, $0.4 \mathrm{Mha}$ ) and hedges (0.8 Mha). In Scenario $2 \mathrm{~b}$, the fallow land would only be reduced by 1.1 Mha. A similar reduction (1 Mha) would be seen in the crop area of feed barley and hay vetch, which, in this scenario, would not be so necessary to provide flows of $\mathrm{N}$ for fertilization in organic farming. In contrast, there would be an increase of 0.9 Mha in the crop area devoted to green manure and 0.5 Mha in that devoted to arable crops (green manure seed production). Likewise, the area occupied by hedges would also rise, to $0.7 \mathrm{Mha}$.

\section{Discussion}

5.1. Discussion of the Different Strategies for the Conversion of Spanish Agriculture to Organic Farming (OF) with Respect to Land Cost

The fall in the yield of Spanish OF with respect to conventional farming methods (23\%) is slightly higher than that found in other comparative studies. Thus, Ponisio et al. report an average fall in yield of $19.2 \%$ in OF, based on a meta-analysis of 115 studies [50], which is similar to that shown by USA authors (20\%) [51]. The low level of funding devoted to the technological development of OF and the lack of training of farmers in appropriate techniques are the main reasons for this reduction, according to the farmers themselves [40]. Organic farms (and therefore the farmers who adopt this approach) are also having to pay the cost of restoring the fund elements of agroecosystems, degraded by industrialized farming [30]. Therefore, it is to be expected that, in the medium to long term, the yield gap between the two methods of farming will be reduced, with no extra land cost, to the extent that research and training funds are made available and the state of the fund elements improves [30,50].

However, it will be difficult to eliminate the yield gap between organic and conventional production without an additional land cost which reduces the significant gap in the input of nitrogen between the two systems. The dose of nitrogen applied by Spanish organic farmers is, in general, very low. The dose of nitrogen fertilizer recommended for conventional wheat is 50-120 kg.ha ${ }^{-1}$ [52] (p. 132) and $80 \mathrm{~kg} \cdot \mathrm{ha}^{-1}$ for rapeseed [53] (p. 170), much higher than the $10 \mathrm{~kg} \cdot \mathrm{ha}^{-1}$ which is received on average by these crops in organic farming. The dose of nitrogen fertilization in summer crops is $259 \mathrm{~kg} \cdot \mathrm{ha}^{-1}$ for corn [54] (p. 141) and 100-220 kg.ha-1 for beet [55] (p. 158), compared with the $87 \mathrm{~kg} \cdot \mathrm{ha}^{-1}$ used on average by organic farmers.

Even with these low nitrogen doses, the expansion of the extensive strategy for conversion to OF does not appear to be very viable. It would be very difficult for the territory of Spain to absorb the impact of such a transformation (Scenario 1). It is not enough to bring fallow land into production. The agricultural land abandoned since 1986, when Spain joined the then European Common Market, would have to be recovered. This latter idea could be controversial, since two-thirds of the land abandoned has been converted to forest (Figure 3). Several authors have questioned the relationship between land abandonment and ecosystem recovery in Spain [56]. These authors hold that the assumed restorative character of the forest transition in the Mediterranean is based on an underestimation of the ecological importance of non-forest habitats. Even so, we believe that intensification strategies under agroecological criteria (Scenarios $2 \mathrm{a}$ and $2 \mathrm{~b}$ ) could make it possible to achieve both the conservation of this land as forest as well as the conversion of Spanish agriculture to OF.

It may be asked why the legume green manure technique is used so little by Spanish organic farmers. This technique has been identified as being central to organic fertilization [57,58]. However, it is very seldom used today in organic fruit orchards and not at all on arable crops. Legume green manures occupy land through seed use and by reducing the intensity of the rotations in which they are included. In fruit orchards, the cost of green manure is due only to legume seed use. However, on arable land, the cost of reducing the intensity of rotation must be added to the land cost of seed use. This is because the legume green manure must totally or partially substitute a rotation crop. The main 
reason is climatic. In regions with a Mediterranean climate, the low rainfall hinders the growth of green manure on dry farming land in the summer, when the land is empty in between the main crops of the rotation. In Spain, dry farming land is $79 \%$ of total cropland [39]. Cultivating green manure in autumn-winter would mean devoting an entire agricultural year to these crops, which is very costly in productive and economic terms. In short, the proposal to sow the green manure in winter and the main crop in summer in order to reduce the impact of the conversion to OF on food production [57] is not possible in Mediterranean regions.

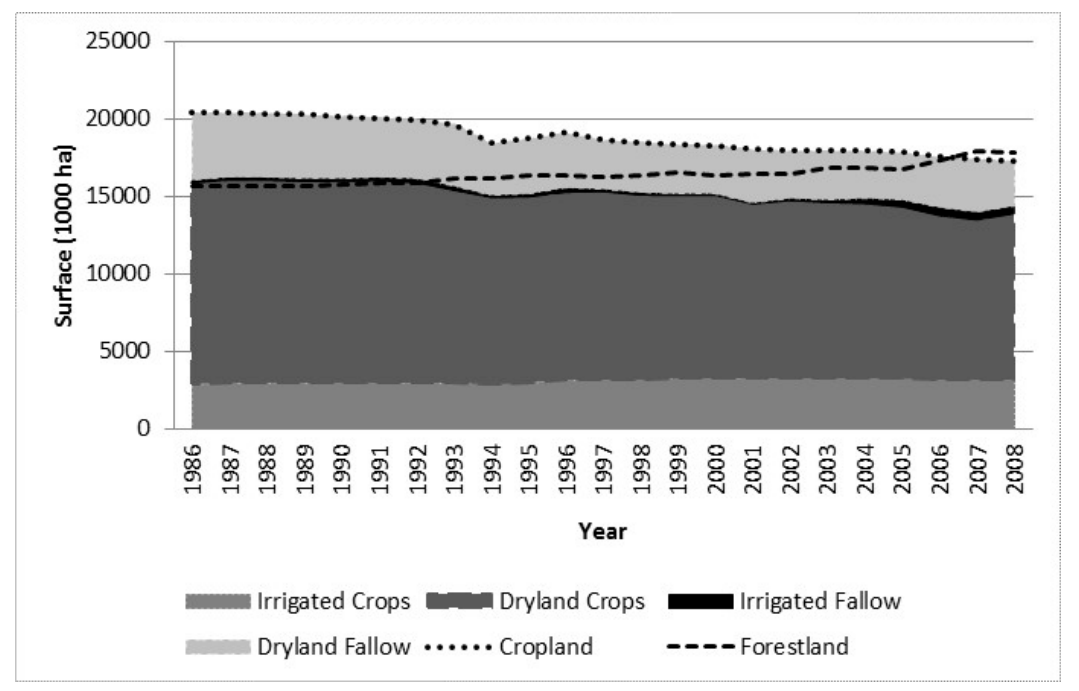

Figure 3. Evolution of Spanish cropland and forestland since joining the European Union (EU).

Theoretically, on irrigated farmland, the input of water would make it possible to grow green manure at any time of the year. However, there are two reasons why this practice is uncommon. The first is the high economic cost of irrigation, which makes it unviable for green manure. The second is the opportunity cost. The soil of irrigated land is used very intensively and the time during which the soil is unoccupied is very short. Thus, the farmers try to make maximum profit from the high costs of investment in this type of agriculture.

Therefore, although the conversion strategy of Scenario $2 \mathrm{~b}$ is more advantageous from the land cost perspective, it is not a realistic scenario. In Scenario 2a, the use of manure involves transferring nutrients from less productive areas (dry farming land devoted to barley and vetch) to other more productive land used to cultivate crops which generate income. This method of specialization of soil use based on its productive potential, in which the more marginal areas transfer nutrients to areas of greater productive potential, is traditional in the Iberian Peninsula [34,59]. Green manure is only effective if it occupies the land that is to be fertilized and must be more frequent where the productive potential of the soil is higher. This means dramatically reducing the intensity of rotations, not just in the best dry farming land, but also in irrigated areas where food production and economic revenue are both higher and, furthermore, they are guaranteed by the irrigation in times of drought. Therefore, although Scenario $2 b$ is, a priori, the most advantageous, Scenario $2 a$ is better adapted to Mediterranean agroclimatic conditions. In practice, a mixed model would almost certainly be developed in which the prices of animal manure and of foodstuffs would play a crucial role in the farmer's decisions.

In all events, both scenarios bring great environmental benefits. Firstly, there would be benefits from the substitution of industrially synthesized nitrogen fertilizers by organic manure (lower leaching, greater energy efficiency, reduction in the greenhouse gas emissions) [60-63]. Furthermore, planting hedges would increase biodiversity, $\mathrm{CO}_{2}$ sequestration and improve the landscape matrix $[64,65]$. 


\subsection{Limits to the Intensification of Organic Farming under Agroecological Criteria}

Having constructed the scenarios for the intensification of organic farming while minimizing the land cost (Scenarios 2a and 2b), we are close to finding the limits of sustainable intensification under agroecological criteria. That is, that the territory can supply the necessary nitrogen flows to increase food production. There would be between 1.2 and 2.3 Mha less of fallow land plus 1.0 Mha of abandoned, non-forest land which could continue to generate $\mathrm{N}$ flows for the intensification process. This area could produce an increase of approximately $13 \%-20 \%$ in the amount of extra N input into agricultural production with current technologies.

It could be argued that the introduction of biodiversity could generate an increase in production due, as well as pest control, to other important services such as the improvement of pollination, the microclimate, etc. [66]. It could also be claimed that organic fertilization is more efficient at reducing losses such as the leaching of nitrogen: it stimulates the biomass and microbial activity in the soil, favoring the availability of phosphorus for the crops and generating pest and disease-suppressing soils [60,67-69]. Conversion to organic farming under agroecological criteria could effectively bring additional medium to long-term advantages whose aggregate effect is difficult to quantify today. Nevertheless, although these synergies would widen the margin for intensification, the limits imposed by territorial structure would remain in place.

\section{Conclusions}

Sustainable, Ecological and Agroecological Intensification are controversial terms, which should be considered carefully by agroecologists and supporters of organic farming since they could be used for the greening of high-external input agriculture. However, the concept may be useful in certain contexts, provided that it is temporary and territorially localized. In our study, we have shown that it is not viable to scale up Spanish Organic Farming today without a parallel reduction of $13 \%$ in agricultural production. Agroecological Intensification would be the only way to close the yield gap of current organic farming by means of low-entropy internal loop strategies which would reduce the land cost of generating the necessary nitrogen flows. However, it must be taken into consideration that these flows would have to be adjusted to the limits established by the structure of Spanish territory.

Supplementary Materials: The following are available online at www.mdpi.com/2071-1050/9/1/86/s1, Table S1: Green manure land cost per $\mathrm{N}$ unit (ha $\cdot \mathrm{kg}^{-1} \mathrm{~N}$ ), Table S2: Manure land cost per $\mathrm{N}$ unit (ha $\left.\mathrm{kg}^{-1} \mathrm{~N}\right)$, Table S3: N in useful manure from livestock fed with Spanish resources in $2008(\mathrm{t})$, Table S4: N fixed by legume green manure $\left(\mathrm{kg} \cdot \mathrm{ha}^{-1}\right)$, Table S5: $\mathrm{N}$ provided by agroindustrial waste $(\mathrm{t})$.

Acknowledgments: This work springs from the international research project on Sustainable Farm Systems: Long-Term Socio-Ecological Metabolism in Western Agriculture funded by the Social Sciences and Humanities Research Council of Canada and Spanish research project HAR2015-69620-C2-2 funded by Ministerio de Economía y Competitividad (Spain).

Author Contributions: This paper was elaborated jointly, although Gloria I. Guzmán was more concerned with the case study and Manuel González de Molina of the first section, more theoretical.

Conflicts of Interest: The authors declare no conflict of interest.

\section{References}

1. Food and Agriculture Organization (FAO). Global Agriculture towards 2050. Report from the High-Level Expert Forum 'How to Feed the World 2050'. 2009. Available online: http://www.fao.org/fileadmin/ templates/wsfs/docs/Issues_papers/HLEF2050_Global_Agriculture.pdf (accessed on 4 May 2014).

2. Northwest Area Foundation. A Better Row to Hoe: The Economic, Environmental and Social Impact of Sustainable Agriculture; Northwest Area Foundation: St. Paul, MN, USA, 1994.

3. Hewitt, T.; Smith, K. Intensive Agriculture and Environmental Quality: Examining the Newest Agricultural Myth; Henry Wallace Institute for Alternative Agriculture: Greenbelt, MD, USA, 1995. 
4. Reardon, T.; Crawford, E.; Kelly, V.; Diagana, B. Promoting Farm Investment for Sustainable Intensification of African Agriculture; Technical Paper No. 26; Michigan State University: East Lansing, MI, USA, 1995. Available online: http:/ /pdf.usaid.gov/pdf_docs/pnaec391.pdf (accessed on 10 January 2014).

5. Pretty, J. The sustainable intensification of agriculture. Nat. Resour. Forum 1997, 21, 247-256. [CrossRef]

6. Tilman, D.; Balzer, C.; Hill, J.; Befort, B.L. Global Food Demand and the Sustainable Intensification of Agriculture. Proc. Natl. Acad. Sci. USA 2011, 108, 20260-20264. [CrossRef] [PubMed]

7. Pretty, J.; Bharucha, Z.P. Sustainable intensification in agricultural systems. Ann. Bot. 2014, 114, 1571-1596. [CrossRef] [PubMed]

8. The Royal Society. Reaping the Benefits: Science and the Sustainable Intensification of Global Agriculture; The Royal Society: London, UK, 2009; pp. 1-72.

9. Garnett, T.; Appleby, M.C.; Balmford, A.; Bateman, I.J.; Benton, T.G.; Bloomer, P.; Burlingame, B.; Dawkins, M.; Dolan, L.; Fraser, D.; et al. Sustainable intensification in agriculture: Premises and policies. Science 2013, 341, 33-34. [CrossRef] [PubMed]

10. Foundation for Rural Investment Support for Europe (RISE). Available online: http:/ /www.risefoundation. eu/projects/sustainable-intensification) (accessed on 7 June 2016).

11. Garnett, T.; Godfray, C. Sustainable Intensification in Agriculture. Navigating a Course through Competing Food System Priorities; Food Climate Research Network and the Oxford Martin Programme on the Future of Food, University of Oxford: Oxford, UK, 2012. Available online: http://www.fcrn.org.uk/sites/default/files/SI_ report_final.pdf (accessed on 12 January 2014).

12. Buckwell, A.; Nordang Uhre, A.; Williams, A.; Jana Poláková, J.; Blum, W.E.; Schiefer, J.; Lair, G.J.; Heissenhuber, A.; Schießl, P.; Krämer, C.; et al. The Sustainable Intensification of European Agriculture; RISE Foundation: Brussels, Belgium, 2014. Available online: http://www.risefoundation.eu/images/ files/2014/2014_SI_Brief.pdf (accessed on 30 October 2015).

13. Lang, T.; Barling, D. Food security and food sustainability: Reformulating the debate. Geogr. J. 2012, 178, 313-326. [CrossRef]

14. Loos, J.; Abson, D.J.; Chappell, M.J.; Hanspach, J.; Mikulcak, F.; Tichit, M.; Fischer, J. Putting meaning back into "sustainable intensification". Front. Ecol. Environ. 2014, 12, 356-361. [CrossRef]

15. Rudel, T.K.; Schneider, L.; Uriarte, M.; Turner, B.L., II; DeFries, R.; Lawrence, D.; Geoghegan, J.; Hecht, S.; Ickowitz, A.; Lambin, E.F.; et al. Agricultural intensification and changes in cultivated areas, 1970-2005. Proc. Natl. Acad. Sci. USA 2009, 106, 20675-20680. [CrossRef] [PubMed]

16. Borlaug, N. Feeding a hungry world. Science 2007, 318, 359. [CrossRef] [PubMed]

17. Cassman, K.G. Ecological intensification of cereal production systems: Yield potential, soil quality, and precision agriculture. Proc. Natl. Acad. Sci. USA 1999, 96, 5952-5959. [CrossRef] [PubMed]

18. Chevassus-au-Louis, B.; Griffon, M. La Nouvelle Modernité: Une Agriculture Productive à Haute Valeur Ecologique. 2008. Available online: http://clubdemeter.com/pdf/ledemeter/2008/la_nouvelle_modernite_ une_agriculture_productive_a_haute_valeur_ecologique.pdf (accessed on 1 September 2016).

19. Garbach, K.; Milder, J.C.; DeClerck, F.A.; de Wit, M.A.; Driscoll, L.; Gemmill-Herren, B. Examining multi-functionality for crop yield and ecosystem services in five systems of agroecological intensification. Int. J. Agric. Sustain. 2016, 22. [CrossRef]

20. Food and Agriculture Organization (FAO). State of Land and Water; FAO: Roma, Italy, 2011.

21. UK Government Office for Science. Foresight. The Future of Global Food and Farming; Final Project Report; Government Office for Science London: London, UK, 2011.

22. Titonell, P. Farming Systems Ecology. Towards Ecological Intensification of World Agriculture; Inaugural Lecture upon Taking up the Position of Chair in Farming Systems Ecology at Wageningen University on 16 May 2013; Wageningen University: Wageningen, The Netherlands, 2013. Available online: http://www.wur.nl/upload_mm/8/3/e/8b4f46f7-4656-4f68-bb11-905534c6946c_Inaugural\% 20lecture\%20Pablo\%20Tittonell.pdf (accessed on 20 March 2014).

23. Gliessman, S.R. Agroecology. Ecological Processes in Sustainable Agriculture, 1st ed.; Ann Arbor Press: Chelsea, MA, USA, 1998.

24. De Schüter, O. Report submitted by the Special Rapporteur on the right to food. In Human Rights Council. Sixteenth Session; United Nations, General Assembley: New York, NY, USA, 2010.

25. Nicholls, C.I.; Altieri, M.A.; Vazquez, L. Agroecology: Principles for the Conversion and Redesign of Farming Systems. J. Ecosyst. Ecogr. 2016. [CrossRef] 
26. Georgescu-Roegen, N. The Entropy Law and the Economic Process, 1st ed.; Harvard University Press: Cambridge, UK, 1971.

27. Ho, M.W. Are sustainable economic systems like organisms? In Sociobiology and Bioeconomics, 1st ed.; Koslowski, P., Ed.; Springer: Berlin, Germany, 1998; pp. 237-258.

28. Ho, M.W.; Ulanowicz, R. Sustainable systems as organisms? BioSystems 2005, 82, 39-51. [CrossRef] [PubMed]

29. Ho, M.W. Circular Thermodynamics of Organisms and Sustainable Systems. Systems 2013, 1, 30-49. [CrossRef]

30. Guzmán, G.I.; de Molina, M.G. Energy in Agroecosystems. A Tool for Assessing Sustainability, 1st ed.; CRC Press: Boca Raton, FL, USA, 2017; p. 399.

31. Adriaensen, F.; Chardon, J.P.; De Blust, G.; Swinnen, E.; Villalba, S.; Gulinck, H.; Matthysen, E. The application of "least-cost" modelling as a functional landscape model. Landsc. Urban Plan. 2003, 64, 233-247. [CrossRef]

32. Murphy, H.T.; Lovett-Doust, J. Context and connectivity in plant metapopulations and landscape mosaics: Does the matrix matter? Oikos 2004, 105, 3-14. [CrossRef]

33. Poiani, K.A.; Richter, B.D.; Anderson, M.G.; Richter, H.E. Biodiversity conservation at multiple scales: Functional sites, landscapes, and networks. BioScience 2000, 50, 133-146. [CrossRef]

34. Guzmán, G.I.; González de Molina, M. Preindustrial agriculture versus organic agriculture. The land cost of sustainability. Land Use Policy 2009, 26, 502-510. [CrossRef]

35. Guzmán, G.I.; de Molina, M.G.; Alonso, A.M. The land cost of agrarian sustainability. An assessment. Land Use Policy 2011, 28, 825-835. [CrossRef]

36. De Molina, M.G.; Toledo, V.M. Metabolismos, Naturaleza e Historia, 1st ed.; Icaria Editorial: Barcelona, Spain, 2011.

37. De Molina, M.G.; Toledo, V.M. Social Metabolisms: A Theory on Socio-Ecological Transformations, 1st ed.; Springer: New York, NY, USA, 2014.

38. Vandermeer, J.H. Intercropping. In Agroecology, 1st ed.; Carroll, C.R., Vandermeer, J.H., Rosset, P., Eds.; McGraw Hill: New York, NY, USA, 1990; pp. 481-516.

39. MAGRAMA (Ministerio de Agricultura, Alimentación y Medio Ambiente). Anuario de Estadística. 2008. Available online: http://www.magrama.gob.es/es/estadistica/temas/publicaciones/anuario-deestadistica (accessed on 4 February 2016).

40. Alonso, A.M.; Guzmán, G.I.; Foraster Pulido, L.; González Lera, R. Impacto socioeconómico y ambiental de la agricultura ecológica en el desarrollo rural. In Producción Ecológica. Influencia en el Desarrollo Rural, 1st ed.; Guzmán, G.I., García, A.R., Alonso, A.M., Perea, J.M., Eds.; MARM: Madrid, Spain, 2008; pp. 71-266.

41. Alonso, A.M.; Guzmán, G.I. Comparison of the Efficiency and Use of Energy in Organic and Conventional Farming in Spanish Agricultural Systems. J. Sustain. Agric. 2010, 34, 312-338. [CrossRef]

42. Asociación Nacional de Fabricantes de Fertilizantes (ANFFE). Evolución del Consumo de Fertilizantes Químicos en España. Available online: http://www.anffe.com/informaci\%F3n\%20sectorial/evoluci\%F3n\% 20del\%20consumo/index.html (accessed on 29 March 2014).

43. MAGRAMA (Ministerio de Agricultura, Alimentación y Medio Ambiente). Balance del Nitrógeno en la Agricultura Española. Año 2013. Available online: http:/ /www.mapama.gob.es/es/agricultura/temas / medios-de-produccion/bn2013_metodologia-resultados_tcm7-421744.pdf (accessed on 10 May 2016).

44. Nicholls, C.I.; Parrella, M.; Altieri, M.A. The effects of a vegetational corridor on the abundance and dispersal of insect biodiversity within a northern California organic vineyard. Landsc. Ecol. 2001, 16, 133-146. [CrossRef]

45. Miñarro, M.; Prida, E. Hedgerows surrounding organic apple orchards in north-west Spain: Potential to conserve beneficial insects. Agric. For. Entomol. 2013. [CrossRef]

46. García-Ruiz, R.; González de Molina, M.; Guzmán, G.I.; Soto, D.; Infante, J. Guidelines for constructing nitrogen, phosphorus and potassium balances in historical agricultural systems. J. Sustain. Agric. 2012, 36, 650-682. [CrossRef]

47. Moreno, M.M.; Lacasta, C.; Meco, R.; Moreno, C. Rainfed crop energy balance of different farming systems and crop rotations in a semi-arid environment: Results of a long-term trial. Soil Tillage Res. 2011, 114, 118-127. [CrossRef]

48. Gustavsson, J.; Cederberg, C.; Sonesson, U.; van Otterdijk, R.; Meybeck, A. Global Food Losses and Food waste. Extent, causes and prevention. In Study Conducted for the International Congress Save Food! At Interpack 2011. Düsseldorf, Germany; FAO: Roma, Italy, 2011. 
49. Food and Agriculture Organisation of United Nations (FAO). FAOSTAT_FAO Database for Food and Agriculture; Food and Agriculture Organisation of United Nations (FAO): Rome, Italy, 2015. Available online: http:/ / faostat3.fao.org/ (accessed on 15 January 2015).

50. Ponisio, L.C.; M'Gonigle, L.K.; Mace, K.C.; Palomino, J.; de Valpine, P.; Kremen, C. Diversification practices reduce organic to conventional yield gap. Proc. R. Soc. B Biol. Sci. 2015, 282. [CrossRef]

51. Kniss, A.R.; Savage, S.D.; Jabbour, R. Commercial Crop Yields Reveal Strengths and Weaknesses for Organic Agriculture in the United States. PLoS ONE 2016, 11, e0161673. [CrossRef] [PubMed]

52. López Bellido, L. Abonado de los cereales de invierno: Trigo y cebada. In Guía Práctica de la Fertilización Racional de los Cultivos en España; Parte II; MAGRAMA: Madrid, Spain, 2010; pp. 123-132.

53. Urbano Terrón, P. Abonado de las oleaginosas herbáceas: Girasol, soja y colza. Abonado de cultivos industriales: Remolacha azucarera y algodón. In Guía Práctica de la Fertilización Racional de los Cultivos en España; MAGRAMA: Madrid, Spain, 2010; Part II, pp. 165-171.

54. Betrán Aso, J. Abonado de los cereales de primavera: Maíz. In Guía Práctica de la Fertilización Racional de los Cultivos en España; MAGRAMA: Madrid, Spain, 2010; Part II, pp. 135-141.

55. Bermejo Corrales, J.L. Abonado de cultivos industriales: Remolacha azucarera y algodón. In Guía Práctica de la Fertilización Racional de los Cultivos en España; MAGRAMA: Madrid, Spain, 2010; Part II, pp. 155-164.

56. Otero, I.; Marull, J.; Tello, E.; Diana, G.L.; Pons, M.; Coll, F.; Boada, M. Land abandonment, landscape, and biodiversity: Questioning the restorative character of the forest transition in the Mediterranean. Ecol. Soc. 2015, 20, 7. [CrossRef]

57. Badgley, C.; Moghtader, J.; Quintero, E.; Zakem, E.; Chappell, M.J.; Avilés-Vázquez, K.; Samulon, A.; Perfecto, I. Organic agriculture and the global food supply. Renew. Agric. Food Syst. 2007, 22, 86-108. [CrossRef]

58. Billen, G.; Garnier, J.; Lassaletta, L. The nitrogen cascade from agricultural soils to the sea: Modelling nitrogen transfers at regional watershed and global scales. Philos. Trans. R. Soc. B 2013, 368, 20130123. [CrossRef] [PubMed]

59. Cussó, X.; Garrabou, R.; Tello, E. Social metabolism in an agrarian region of Catalonia (Spain) in 1860-1870: Flows, energy balance and land use. Ecol. Econ. 2006, 58, 49-65. [CrossRef]

60. Rodale Institute. The Farming Systems Trials. Celebrating 30 Years. 2011. Available online: http:// rodaleinstitute.org/assets/FSTbooklet.pdf (accessed on 11 February 2016).

61. Smith, L.G.; Williams, A.G.; Pearce, B.D. The energy efficiency of organic agriculture: A review. Renew. Agric. Food Syst. 2015, 30, 280-301. [CrossRef]

62. Aguilera, E.; Guzmán, G.I.; Alonso, A.M. Greenhouse gas emissions from conventional and organic cropping systems in Spain. I. Herbaceous crops. Agron. Sustain. Dev. 2015, 35, 713-724. [CrossRef]

63. Aguilera, E.; Guzmán, G.I.; Alonso, A.M. Greenhouse gas emissions from conventional and organic cropping systems in Spain. II. Fruit tree orchards. Agron. Sustain. Dev. 2015, 35, 725-737. [CrossRef]

64. EPA (Environmental Protection Agency). Carbon Sequestration by Hedgerows in the Irish Landscape. Climate Change Research Programme (CCRP) 2007-2013 Report Series No. 32. 2014. Available online: http:/ / www.birdwatchireland.ie/LinkClick.aspx?fileticket=Csbqc9wMq1s\%3D\&tabid=1439 (accessed on 15 September 2016).

65. Lecq, S.; Loisela, A.; Brischoux, F.; Mullin, S.J.; Bonnet, X. Importance of ground refuges for the biodiversity in agricultural hedgerows. Ecol. Indic. 2017, 72, 615-626. [CrossRef]

66. Kumaraswamy, S.; Kunte, K. Integrating biodiversity and conservation with modern agricultural landscapes. Biodivers. Conserv. 2013, 22, 2735-2750. [CrossRef]

67. Sharma, S.B.; Sayyed, R.Z.; Trivedi, M.H.; Gobi, T.A. Phosphate solubilizing microbes: Sustainable approach for managing phosphorus deficiency in agricultural soils. SpringerPlus 2013, 2, 587. [CrossRef] [PubMed]

68. Gallaher, C.; Snapp, S.S. Organic management and legume presence maintained phosphorus bioavailability in a 17-year field crop experiment. Renew. Agric. Food Syst. 2015, 30, 211-222. [CrossRef]

69. Bruggen, A.H.C.; van Finckh, M.R. Plant Diseases and Management Approaches in Organic Farming Systems. Annu. Rev. Phytopathol. 2016, 54, 25-54. [CrossRef] [PubMed]

(C) 2017 by the authors; licensee MDPI, Basel, Switzerland. This article is an open access article distributed under the terms and conditions of the Creative Commons Attribution (CC-BY) license (http:/ / creativecommons.org/licenses/by/4.0/). 